THE ORGANISATION IN ITS ENVIRONMENT 
By the same author

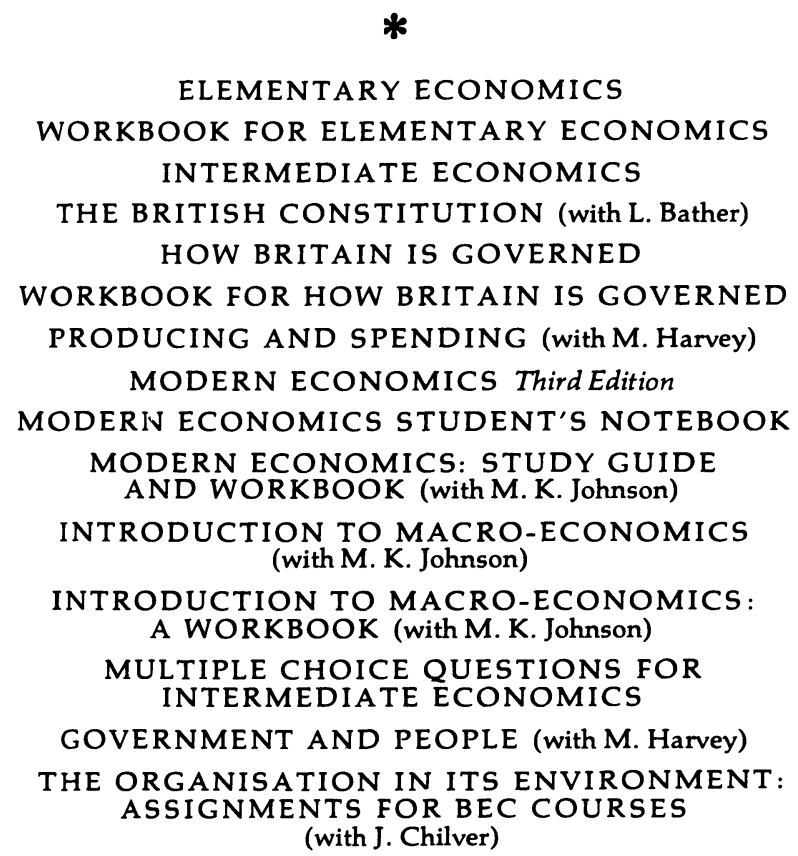




\section{THE ORGANISATION IN ITS ENVIRONMENT}

Business in the Mixed Economy

J. Harvey 


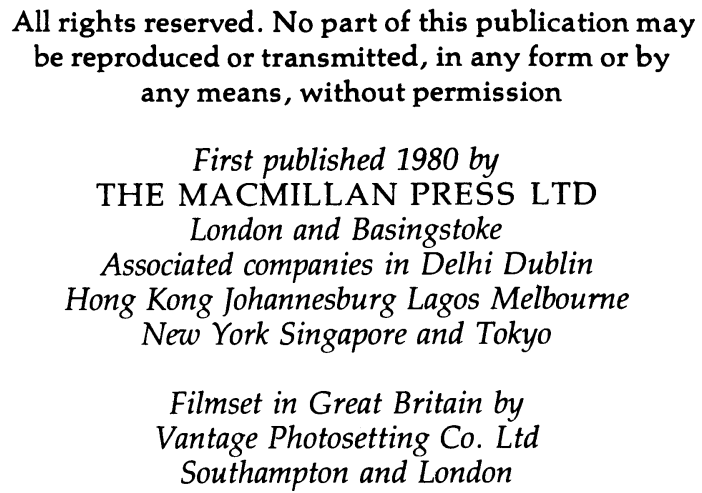

British Library Cataloguing in Publication Data

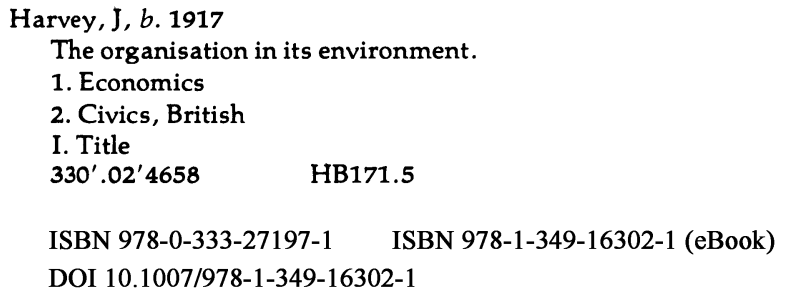

This book is sold subject to the standard conditions of the Net Book Agreement

The paperback edition of this book is sold subject to the condition that it shall not, by way of trade or otherwise, be lent, resold, hired out, or otherwise circulated without the publisher's prior consent, in any form of binding or cover other than that in which it is published and without a similar condition including this condition being imposed on the subsequent purchaser 


\section{Contents}

PART I THE ORGANISATION IN ITS ENVIRONMENT: A PROFILE

1 BUSINESS ORgANISATIONS AND THE ENVIRONMENT

I Production for wants

II The material standard of living 11

III The firm and its environment $\quad 16$

2 The Population as CONSUMers AND PRODUCERS

I The growth of population $\quad 20$

II The implications of changes in the size of the population 23

III The age distribution of the population $\quad 28$

IV The industrial distribution of the working population 30

V The geographical distribution of the population $\quad 32$

3 The BaCKGround to Business ACTIVITY: THE PROBLEM OF SCARCITY

I The economic problem $\quad 35$

II Economic systems $\quad 36$

III The market economy $\quad 37$

IV The command economy 39

V Britain's mixed economy $\quad 41$

PART II THE GOVERNMENT OF THE UK

4 The Problem of GovernMent

$\begin{array}{ll}\text { I Introduction } & 47\end{array}$

II Parliament $\quad 51$

5 THE GOVERNMENT AND THE ADMINISTRATION
I The Cabinet

II Government departments $\quad 60$

III The Civil Service $\quad 66$

6 THe Legal Framework

$\begin{array}{ll}\text { I The nature and role of law } & 71\end{array}$

II The need for courts of justice $\quad 72$

$\begin{array}{ll}\text { III Criminal jurisdiction } & 73\end{array}$

$\begin{array}{ll}\text { IV Civil jurisdiction } & 75\end{array}$

$\begin{array}{ll}\mathrm{V} \text { Administrative justice } & 77\end{array}$ 
$\begin{array}{ll}\text { VI Arbitration } & 80\end{array}$

VII Forms of firms' legal liability $\quad 80$

VIII Making contracts $\quad 82$

\section{PART III THE MARKET ECONOMY}

7 THE OPERATION OF THE FREE MARKET

I Markets $\quad 91$

II Forces determining price $\quad 96$

III The determination of price: market-clearing 102

IV Changes in the conditions of demand and supply 103

$\begin{array}{ll}\mathrm{V} \text { The functions of price in the free market } & 105\end{array}$

$\begin{array}{ll}\text { VI Further applications } & 108\end{array}$

8 THE FIRM AND ITS CUSTOMERS

I The role of the firm $\quad 111$

II What to produce: marketing strategy 113

III Elasticity of demand $\quad 117$

IV The distribution of goods to the consumer 121

$\begin{array}{ll}\mathrm{V} \text { Consumer protection } & 128\end{array}$

9 HOW TO PRODUCE: GeNERAL PRINCIPLES

$\begin{array}{ll}\text { I The division of labour } & 131\end{array}$

II The advantages of large-scale production 133

$\begin{array}{ll}\text { III The size of firms } & 135\end{array}$

IV The functional organisation of the firm 139

V Combining resources $\quad 144$

VI The costs of production $\quad 148$

10 THE FIRM'S OUTPUT: HOW MUCH TO PRODUCE

I Output under perfect competition $\quad 154$

$\begin{array}{ll}\text { II Elasticity of supply } & 160\end{array}$

III Monopoly 163

IV Monopolistic competition $\quad 172$

$\begin{array}{ll}\mathrm{V} \text { Oligopoly, and pricing in practice } & 173\end{array}$

11 LABOUR

I The nature of the labour force 176

II Determination of the rate of pay 177

III Trade unions and collective bargaining 185

$\begin{array}{ll}\text { IV Worker protection } & 193\end{array}$

12 OCCUPYING PREMISES

I The location of the business 197

II Determination of the cost of land 200

III Obligations of the occupiers of premises 203

13 CAPITAL: ITS SOURCES AND EMPLOYMENT

I The firm's need for liquid capital $\quad 206$

II Money markets $\quad 209$ 
III The capital market $\quad 213$

IV The Stock Exchange $\quad 215$

V Methods of financing a company $\quad 219$

VI Investment in fixed capital $\quad 222$

VII Industrial property $\quad 226$

VIII The responsibilities of an organisation to those who contribute $\begin{array}{ll}\text { capital } & 227\end{array}$

IX Insolvency $\quad 230$

\section{PART IV THE PUBLIC SECTOR}

14 The Allocation of Resources through the Public Sector

I Introduction $\quad 235$

II The government department $\quad 236$

III Local authorities $\quad 240$

IV The nationalised industries $\quad 250$

$\begin{array}{ll}\mathrm{V} \text { Other quasi-government bodies } & 257\end{array}$

\section{PART V GOVERNMENT STABILISATION POLICY}

15 GOVERNMENT DiRECTION OF THE ECONOMY

I Introduction $\quad 261$

II Measuring the national income $\quad 261$

16 CYCLICAL FluCtUATIONS IN INCOME AND EMPLOYMENT

I The nature of unemployment $\quad \mathbf{2 7 2}$

II The link between spending and production $\quad 275$

III Reasons for changes in aggregate demand $\quad 277$

$\begin{array}{ll}\text { IV Consumption and saving } & 278\end{array}$

V Investment spending $\quad 282$

VI The control of cyclical unemployment $\quad 284$

17 BalanCED Regional DEVElopMent

I The nature of the problem $\quad 289$

II Government policy 290

18 CURRENCY STABILITY

I The effects of inflation $\quad 295$

II Measuring changes in the general level of prices 296

III Money 298

IV The creation of credit $\quad 299$

V Bank lending policy 302

VI Controlling the supply of money 305

19 THE REDISTRIBUTION OF INCOME

I Government expenditure $\quad 309$

II The modern approach to taxation $\quad 310$

$\begin{array}{ll}\text { III The structure of taxation } & 315\end{array}$ 
viii Contents

20 INTERNATIONAL TRADE

I Why international trade?

320

II Pattern of UK overseas trade

323

III Free trade and protection

IV The balance of payments

$\mathrm{V}$ Balance of payments problems

338

VI International institutions

VII The European Economic Community

21 THE COMMUNITY AND ORGANISATIONS

I A review

II Influencing organisations

Index 


\section{Preface}

The primary aim of this book is to provide a basic text covering 'The Organisation in its Environment', the common core modules 3 and 4 of the Business Education Council (BEC) National Awards. It could also be used as an introduction to Higher National Awards courses.

Because the syllabus draws on a number of disciplines - in particular economics, government and politics, and law - a textbook can adopt alternative approaches. First, it could take the learning objectives of the BEC syllabus, dealing with each in turn. The weakness of this is that it might simply describe topics in a rather unrelated way. Second, it can give a bird's-eye view of how the UK is organised to provide the goods and services required by the community, explaining principles, suggesting reasons and provoking thought, but at the same time seeking to integrate the syllabus topics within the broad structure. The latter is the method adopted by this book. But, to reassure teachers and students that the learning objectives are covered, the relevant chapters are indicated on page $x$.

The 'organisation' is interpreted widely, covering firms in the private sector and government departments, the nationalised industries, local authorities and other quasigovernment bodies in the public sector. While such organisations may differ in structure and objectives, all are engaged in some form of production and the book shows how they are interrelated through this.

Nevertheless, their particular operations are so complex that rarely can their policies be explained by reference to a single section of the text. Thus the real task of analysing real-life situations and of integrating modules and the general and learning objectives is reserved for the exercises and projects provided in the accompanying workbook. In short, the textbook should be regarded primarily as the basic tool-kit which can be used to unravel the actual problems facing all organisations.

At all times, the needs of beginners have been kept uppermost. As far as possible, the formal disciplines of economics, government, law, etc., have been avoided. Nevertheless, especially when a topic falls mainly within the field of economics, some elementary theory to show how analysis can proceed has been introduced. This has two main advantages: first, there is nothing so practical as sound theory; second, should the student wish to proceed later to a more formal study of economics, his thinking will already have been directed along the right lines.

In conclusion I would like to thank my two editors, Nick Brealey and John Winckler, for their enthusiasm, encouragement and hard work, without which this book could not have been possible. 
x Preface

\section{Coverage of learning objectives}

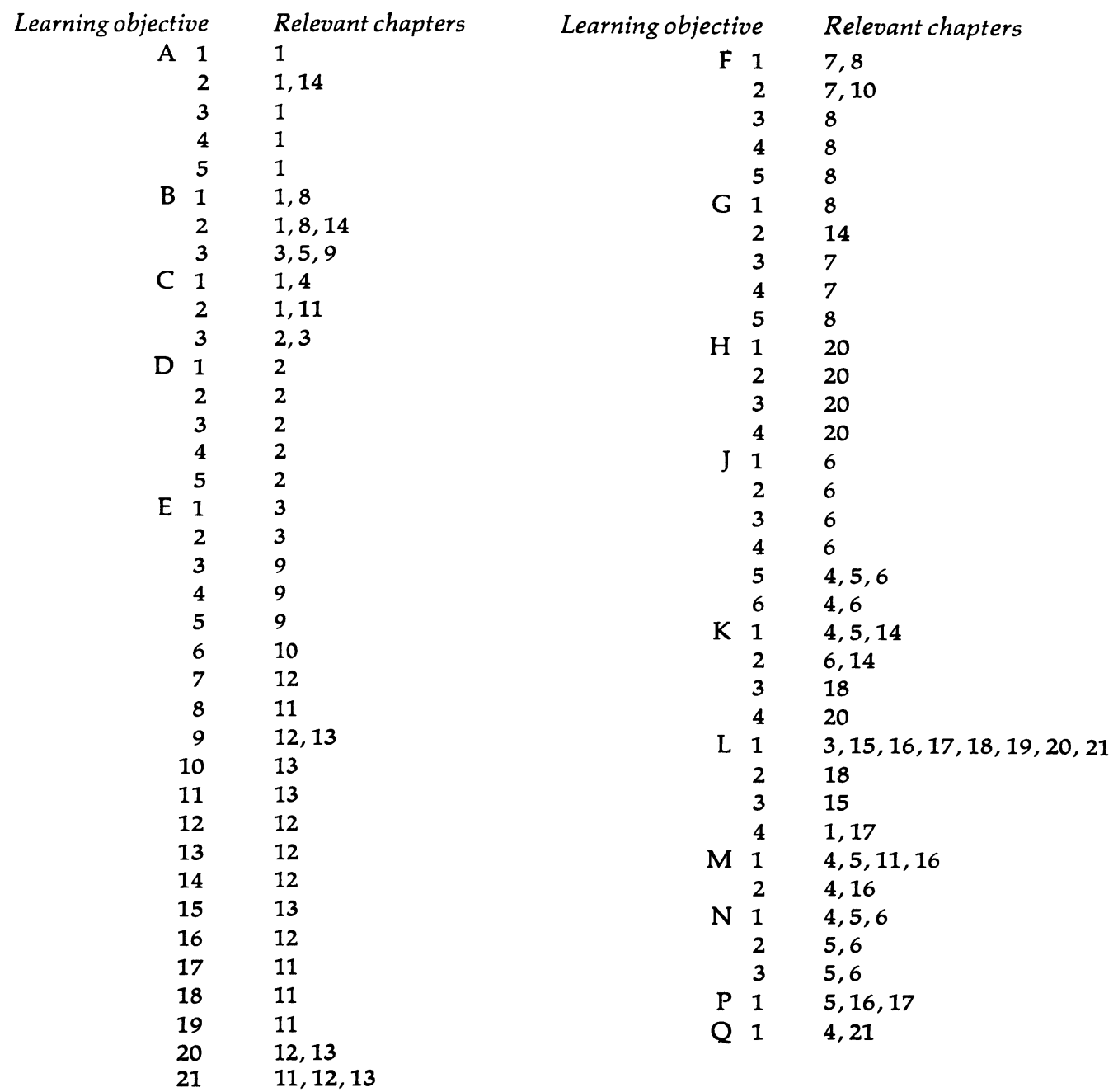

